\title{
Assessment of Irrigation Land Suitability for Surface Irrigation in Birbir River Watershed Using Geographic Information System Technique in Oromia Region, Ethiopia
}

\author{
Garuma Negasa ${ }^{1}$, Gutema Wakjira ${ }^{2}$ \\ ${ }^{1}$ Water Resources and Hydraulic Engineering, Engineering and Technology, Wollega University, Nekemte, Ethiopia \\ ${ }^{2}$ Surveying Engineering, Civil Environmental Engineering, Jimma University, Jimma, Ethiopia
}

Email address:

garuma3negasa@mail.com (G. Negasa)

\section{To cite this article:}

Garuma Negasa, Gutema Wakjira. Assessment of Irrigation Land Suitability for Surface Irrigation in Birbir River Watershed Using Geographic Information System Technique in Oromia Region, Ethiopia. Software Engineering. Vol. 9, No. 2, 2021, pp. 45-52.

doi: $10.11648 /$ j.se.20210902.12

Received: July 21, 2021; Accepted: August 10, 2021; Published: August 24, 2021

\begin{abstract}
The planning process of surface irrigation has to integrate information about the suitability of the land, water resource availability and water requirements of irrigable areas in time and place. Birbir River is one of well-known river found in western Ethiopia. The Birbir River is a tributary of the Baro-Akobo river basin, which creates Baro River when it joins with Gebba River. Ethiopia has immense potential in expanding irrigation using available water resources. But due to lack of information related to cultivable and irrigation suitability of the land, its agricultural system does not yet fully productive. Geographic Information System can be an effective tool in identifying irrigable land and mapping of suitable land for irrigation. Therefore, the objective of the present study is to assess the surface irrigation potential land suitability of the Birbir river watershed using ArcGIS 10.3 and Soil and water assessment tool software. Different methods of data processing and analysis have been employed in this study. The main suitability parameters used to identify the irrigation land suitability were slope, soil texture, soil depth, soil type, soil drainage characteristics, land use land cover and distance to water source. The individual suitability of each parameter was first analyzed and finally weighted to get suitable irrigable sites. To reduce the individual biases of factor weighting, the weights of each parameter in the study were determined by using a pairwise comparison method as developed by Satty in the context of the analytical hierarchy process (AHP). By weighting values of the seven factors using Analytic Hierarchy Process and overlaying by weighted overlay in ArcGIS 10.3, the irrigation suitability map was developed and irrigable land area for surface irrigation was found to be $17 \%, 63 \%$ and $20 \%$ for highly suitable S1, moderately suitable S2, and marginally suitable S3 respectively. The total area of the land classified under not suitable $(\mathrm{N})$ class covered was not available. This implies that all lands of the Birbir river watershed can be utilized based on the current irrigation technology.
\end{abstract}

Keywords: Birbir River Watershed, Geographic Information System, Analytical Hierarchy Process, Surface Irrigation Suitability, Suitability Factors

\section{Introduction}

\subsection{Background}

According to the definition of FAO [1], Irrigation is the artificial application of water onto cropland for the purpose of satisfying the water necessary for growing different crops and it plays a key role in stabilizing food production in a number of countries by either supplementing or replacing the need for natural precipitation for the purpose of food production. The area, which can potentially be irrigated, depends on the physical resources, soil and water, combined with the irrigation water requirements as determined by the cropping patterns and climate condition. Irrigation on the free surface offers a number of benefits for the less skilled and poor farmers. Irrigation has contributed significantly to poverty reduction, food security, and improving the quality of life for rural populations. Under such circumstances, more 
than $90 \%$ of the world uses surface irrigation, even if local irrigators have least knowledge of how to operate and maintain the system [2].

Agriculture is the backbone of the Ethiopian economy. It accounts an employment of $90 \%$ of its population, around $50 \%$ of the country's gross domestic product (GDP) and around $90 \%$ of foreign exchange earnings [3]. Ethiopia has been proved to be the" water tower of Africa" however; the use of this water resource is not practiced well in the country. It is estimated about $90 \%$ of the food demand in the country comes from low yield rainfed agriculture. However, Rainfall in the country is varying highly and erratic in time and space [4]. FAO analyzed agricultural production for over 90 less developed country, and the result showed that from a period of 1998 to 2030 it increases by $49 \%$ in rain-fed agriculture and by $81 \%$ by irrigation. Therefore, a higher number of additional foods are expected from an irrigation system as a consequence, it becomes very important to develop and manage all other available water resources in the country [5]. Water has been recognized as the most important factor for the transformation of low productive and low yield rain-fed agriculture into most effective and high productivity irrigated agriculture [6]. About 15 to $17 \%$ of Government expenditures are committed to the agriculture sector [7].

According to the study of MoWE [8], Ethiopian mountains are the source of most rivers (Abay, Awash, Tekeze, Mereb, Baro, Gilo, Akobo and Omo rivers) that flow to the west and southwest. The main capital investment on surface irrigation system is mainly associated with land grading, but if the topography is not too undulating, these costs are not high [9]. Determining the suitability of land for surface irrigation requires thorough evaluation of soil properties and topography (slope) of the land within field [10]. All kinds of rural land are involved by different land-cover land use types; the land suitability evaluation for surface irrigation also provides guidance in cases of conflict between rural land use and urban or industrial expansion, by indicating which areas of land covers land uses are most suitable for irrigation [9].

The planning process of surface irrigation has to integrate information about the suitability of the land, water resource availability and water requirements of irrigable areas in time and place [11]. Assessing the suitability of land for surface irrigation requires thorough evaluation of soil properties and topography (slope) of the land within field [12]. Geographic information system (GIS) and remote sensing (RS) technological applications have now become the common place for the utilities, land surface information and planning. GIS can be an effective tool in identifying suitable irrigable land and mapping of suitable land for irrigation. RS and GIS tools were widely used for the management of water resources [13]. Considering the importance of RS and GIS techniques, the present study was undertaken in Birbir river watershed to assess a suitable land for surface irrigation by evaluating different parameters.

\subsection{Objective of the Study}

The main objective of this study is to assess land suitability for surface irrigation in Birbir river watershed using GIS technique.

\section{Research Methodology}

\subsection{Study Area Description}

The Birbir river is a tributary of the Baro-Akobo river basin, which creates Baro river when it joins with Gebba river at latitude and longitude $8^{\circ} 14^{\prime} 28^{\prime \prime} \mathrm{N} 34^{\circ} 57^{\prime} 39^{\prime \prime} \mathrm{E}$ respectively. The Birbir river watershed covers an area of 634415 ha of land. It is located between the geographical coordinates of $8^{\circ} 27^{\prime} 11^{\prime \prime}$ to $9^{\circ} 24^{\prime} 25^{\prime \prime} \mathrm{N}$ latitude and $34^{\circ} 42^{\prime} 54^{\prime \prime}$ to $35^{\circ} 50^{\prime} 52^{\prime \prime} \mathrm{E}$ longitude and it is located at a distance of $490 \mathrm{~km}$ from Addis Ababa. The annual mean minimum and maximum temperature ranges are $12.0^{\circ} \mathrm{C}$ to $16^{\circ} \mathrm{C}$ and $23.1^{\circ} \mathrm{C}$ to $31^{\circ} \mathrm{C}$ respectively. Rainfall in the region generally varies with variation of altitude. The Annual rainfall of the river watershed is ranging from 1500 to 1800 $\mathrm{mm}$. The agro-climatic condition of the areas alternates with long summer rainfall (June to September) and winter dry season (December to March). The altitude ranges from 1300 to 1800 m.a.s.1.

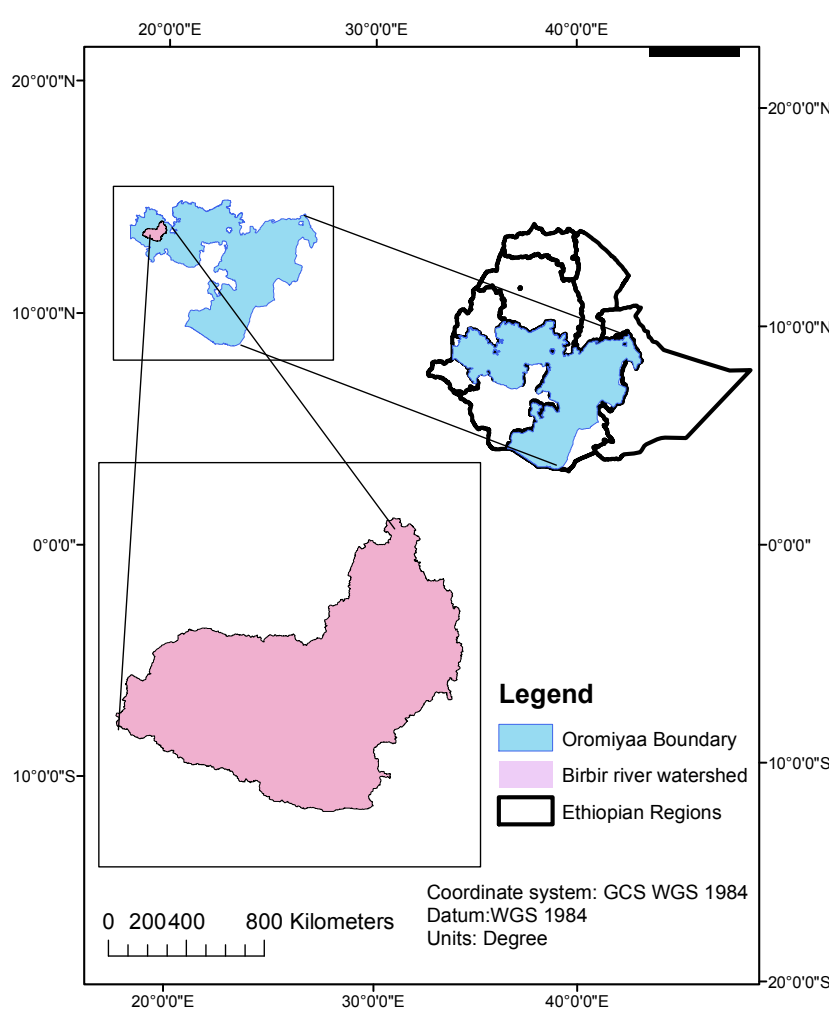

Figure 1. Location map of Birbir river watershed.

\subsection{Data Collection}

Data needed for the modeling work, such as meteorological data (rainfall, temperature, relative humidity, and wind velocity and sunshine hours) data of 24 years period were collected National metrological service agency (NMSA). Stream flow data were obtained from the Ministry of Water, 
Electricity and Energy, Hydrology Department. The watershed physiographic data were collected from Ethiopian Map Agency. Records on soil, land use land cover, slope and drainage systems were collected from Ethiopian Ministry of Water, Electricity and Energy, Geographic information system and remote sensing department. Materials used in this research were ArcGIS 10.3 and Geographic Position System (GPS).

\subsection{Methods of Data Processing and Analysis}

Different methods of data processing and analysis have been employed in this study. Identification of suitable sites for surface irrigation was carried out by considering the slope, soil type, soil texture, soil drainage, soil depth, land cover/use and distance between water supply and the potential command area as factors. In processing all the design and analysis, identifying literature review of the research, and data gathered were analyzed to come up with the research output. The individual suitability of each factor was first analyzed and finally weighted to get suitable irrigable sites. Finally, according to the objectives of the research suitable land map for irrigation was prepared based on GIS analysis. In watershed delineation, the DEM with $30 \times 30$ pixel size, which provides topographic information of the watershed, was used. The study area was delineated using "Soil and water assessment tool (SWAT)" tool in ArcGIS 10.3. The delineated Birbir river watershed covers a total area of 634415 ha.

\subsubsection{Slope Suitability Analysis}

The slope map of the Birbir river watershed was derived using the "Spatial Analysis Slope" tool in ArcGIS 10.3. The Slope that had been derived from the Digital Elevation Model (DEM) was classified based on the classification system of FAO [14] using the "Reclassification" tool, which is an attribute generalization technique in ArcGIS 10.3 interface. The four suitability ranges or slope suitability criteria's are S1 (highly suitable), S2 (moderately suitable), S3 (marginally suitable), and N (not suitable) for surface irrigation.

\subsubsection{Soil Suitability Assessment}

For the assessment of soil suitability for surface irrigation, FAO- soil map of east Africa was used. The major characteristics of soil such as soil types, soil depth, and soil drainage and soil texture in the watershed were then reclassified. By considering those soil physical parameters, irrigation land suitability of the Birbir river watershed was evaluated independently based on the soil classification guideline [15]. Accordingly, soil suitability classes for each parameter with the factor rating of S1, S2, S3, and $\mathrm{N}$ were described in Table 1. Important physical properties of these soil groups were used for irrigation suitability analysis. The rasterized soil map of the watershed was then reclassified based on their soil type name, texture, and depth and drainage classes.

Table 1. Soil suitability factor rating for surface irrigation suitability [15].

\begin{tabular}{lllll}
\hline \multirow{2}{*}{ Soil factors } & Factor rating & & & S3 \\
\cline { 2 - 5 } & S1 & S2 & Imperfect & Poor to very poor \\
\hline Drainage class & Well & Moderate & $50-80$ & $<50$ \\
Depth (mm) & $>100$ & $80-100$ & Sandy, sandy loam & \\
Texture & Loam-Silty Cay, Clay & Silt loam, Sandy Cay & & \\
\hline
\end{tabular}

\subsubsection{Land Use Land Cover (LULC) Analysis}

The LULC type of the birbir river watershed was ranked based on their importance for surface irrigation potential, costs to remove or change for cultivation and environmental impacts under the watershed. According to FAO [16], which are widely used to classify land suitability for specified objectives of land utilization types, a land can be divided in to five suitability classes. These classes include very suitable (S1), suitable (S2), marginally suitable (S3), marginally not suitable (N1) and permanently not suitable (N2).

\subsubsection{Distance from Water Supply}

In order to identify irrigable land close to the Birbir river, straight-line (Euclidean) distance from watershed outlets were calculated using DEM of $30 \mathrm{~m} \times 30 \mathrm{~m}$ cell size by using the buffer icon in the analysis tool and clip to the specified study area. The clipped map of the buffer distance was then converted to raster using the conversion tool and reclassified in to suitability class based on its distance to the water source used "Reclassified tool". The reclassified buffer distance was used for weighting overlay for further analysi with other six factors. Distance between the river and the location of command area needs a subjective judgment in deciding the buffer distances. However, factor such as power capacity of the pumping engine, cost for the high power pumping engines, cost for construction of canals, cost of maintenance of canals and cost of water lost from canal especially for small scale and medium scale irrigation were considered in order to decide the distance between the command area and source of water.

\subsubsection{Weighing of Irrigation Suitability Factors}

Suitable irrigation land of the study area was obtained by creating irrigation suitability model analysis which involved weighting of values of all data sets such as soil types, soil texture, soil drainage, soil depth, slope, land cover and distance. To reduce the individual biases of factor weighting, the weights of each parameter in the study were determined by using a pairwise comparison method as developed by Satty (1980) in the context of the analytical hierarchy process (AHP). All the seven factors, which were selected for the evaluation of Land suitability in the study area, were weighted using pair wise comparison. Land classification parameters are weighted and ranked as follows in table 2. 
Table 2. The standardized results and weight of seven parameters.

\begin{tabular}{lllllllll}
\hline Factors & Slope & Land cover & Soil depth & Soil drainage & Soil texture & Soil type & Distance & Weight (\%) \\
\hline Slope & 1 & 4 & 3 & 4 & 3 & 4 & 5 & 31 \\
Land cover & 0.25 & 1 & 2 & 2 & 2 & 2 & 3 & 20 \\
Soil depth & 0.33 & 0.5 & 1 & 1 & 1 & 1 & 4 & 11 \\
Soil drainage & 0.25 & 0.5 & 1 & 1 & 1 & 1 & 3 & 11 \\
Soil texture & 0.33 & 0.5 & 1 & 1 & 1 & 1 & 2 & 11 \\
Soil type & 0.25 & 0.5 & 1 & 1 & 1 & 1 & 3 & 10 \\
Distance & 0.2 & 0.33 & 0.25 & 0.33 & 0.25 & 0.33 & 1 & 6 \\
\hline
\end{tabular}

So the seven stated above parameters were weighted in above table 2 and the suitability of the land was done using the weight given to each parameters.

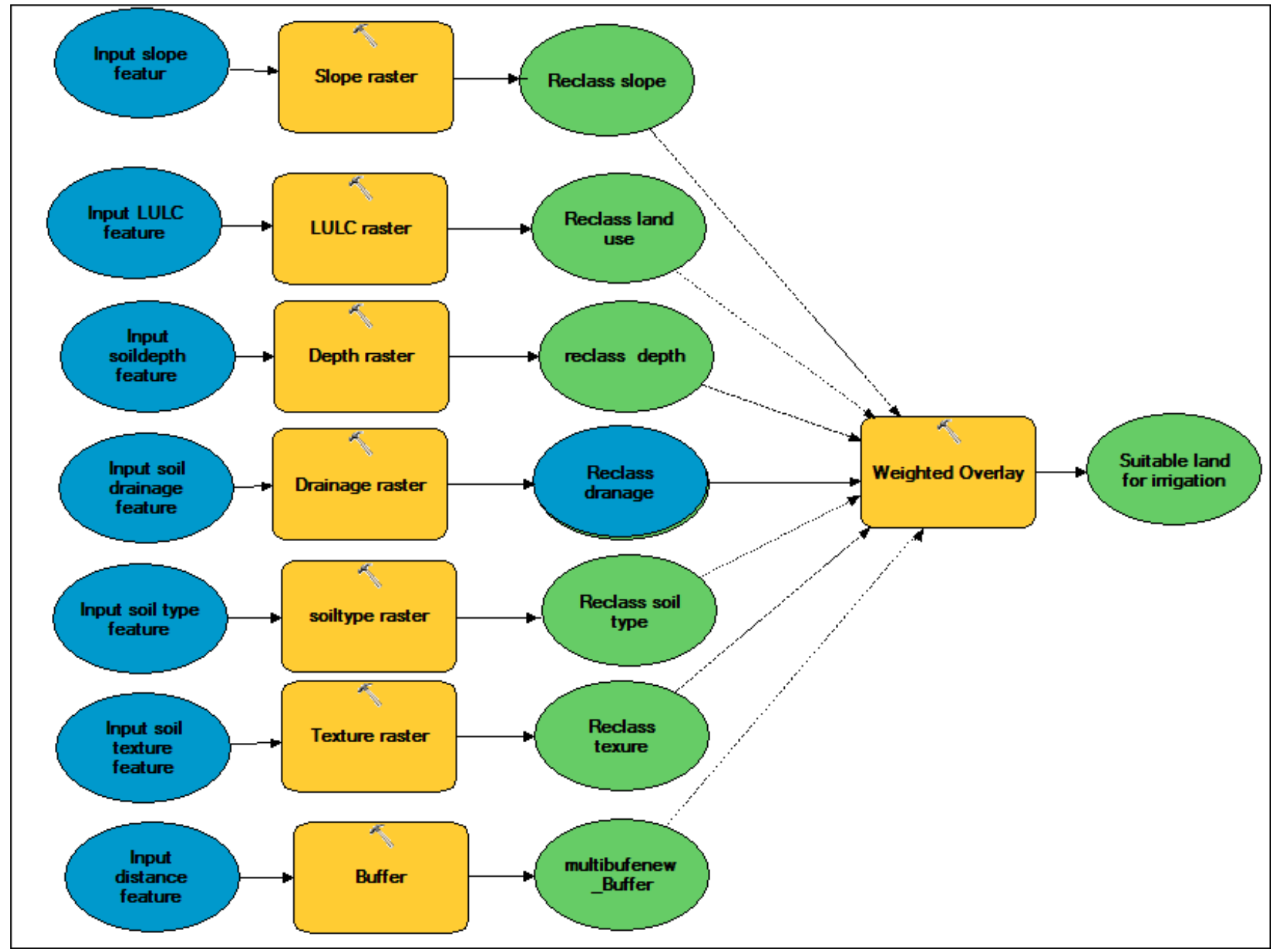

Figure 2. Surface irrigation land suitability model.

\section{Results and Discussions}

\subsection{Irrigation Suitability Analysis}

\subsubsection{Slope Suitability}

The slope suitability analysis of the river watershed revealed that $27.91 \%(174,359$ ha) of the total area was in the range of highly suitable (S1) for surface irrigation. Similarly moderately suitable (S2) range for surface irrigation system is found to be $25.35 \%(158,418 \mathrm{ha})$ of the watershed, were as the remaining $41.14 \%$ (257004 ha) and $5.60 \%$ (34988 ha) of the total area of the Birbir watershed were found to be in the range of marginally suitable (S3) for surface irrigation system and marginally not suitable $(\mathrm{N})$ with respect to slope respectively. Therefore, it is possible to conclude that, more than half Birbir river watershed was found to be highly suitable to moderately suitable for surface irrigation in terms of its work efficiency and cost for land leveling, canal construction and cost for pumping system. The reclassified slope suitability map is shown in the figure 3 . 


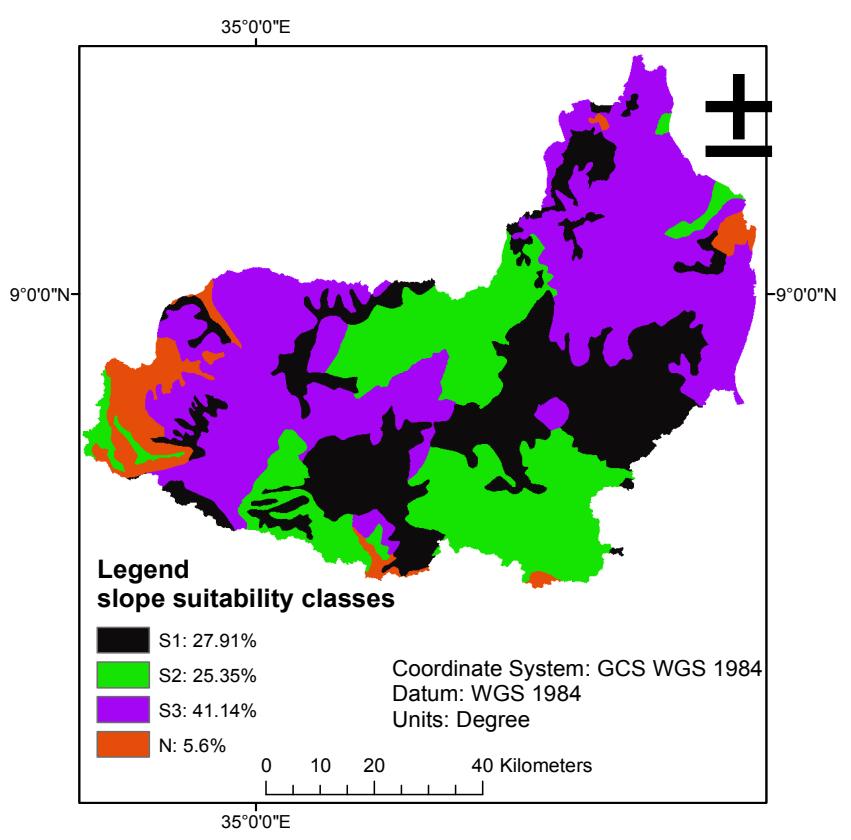

Figure 3. Reclassified slope suitability map the watershed.

\subsubsection{Land Cover Land Use Suitability}

The sixteen land use types of Bibir river watershed were reclassified in to four suitability classes. The reclassified suitability classes of land use land cover of the watershed for the surface irrigation system are shown in figure 4. This result showed that almost one fourth of the river watershed cannot be put under surface irrigation due to the impact of surface irrigation on the environment. Almost half of the Birbir river watershed can be put under irrigation with some limitations which may cost the mitigation of the environment with respect to land use land cover. The result in figure 4 shows highly suitable (S1) class on the map is located at the middle part of the river watershed.

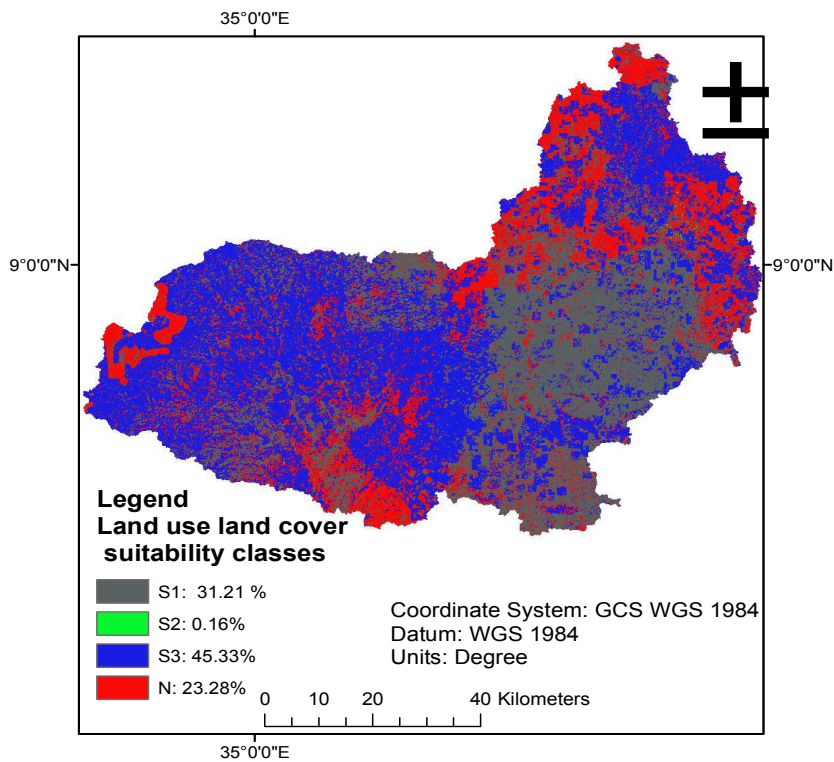

Figure 4. Reclassified land use land cover map of the watershed.

\subsubsection{Soil Texture Suitability}

Based on the FAO, 1985 guideline of land suitability classification, Soil textural classes such as clay, clay loam and loam soil were classified as highly suitable (S1), whereas silt and silty loam were classified as moderately suitable (S2) and sandy loam soil texture was classified as marginally suitable (S3) for surface irrigation with limitation factor of high infiltration rate. The result in figure 5 showed that about half of the total study area was found to be in the range highly suitable.

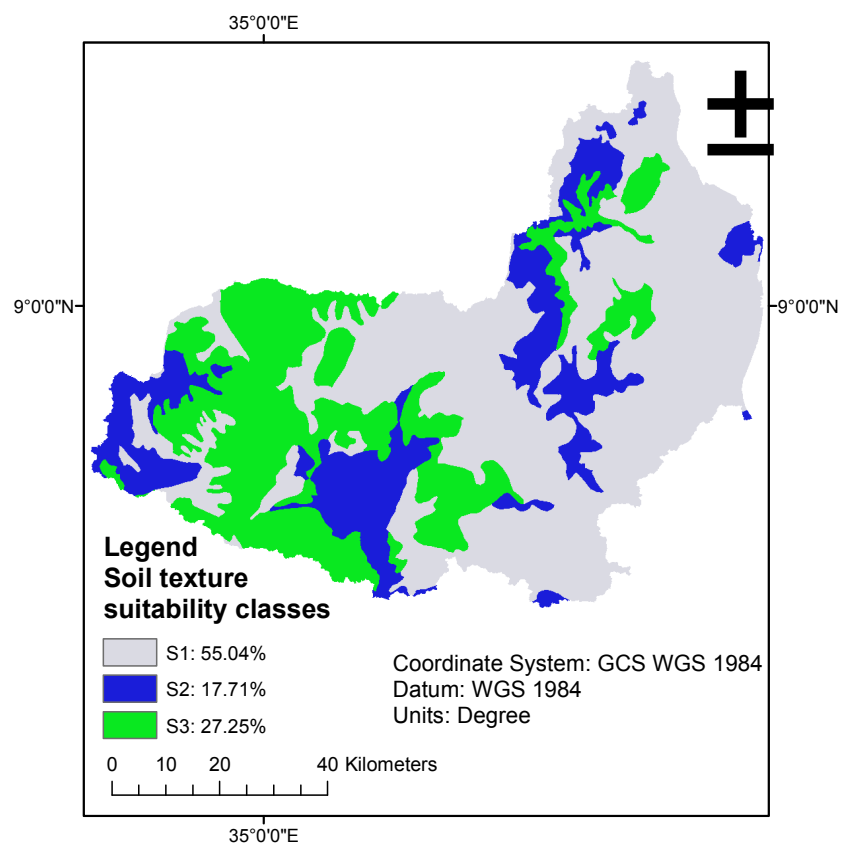

Figure 5. Reclassified soil texture suitability map of the river watershed.

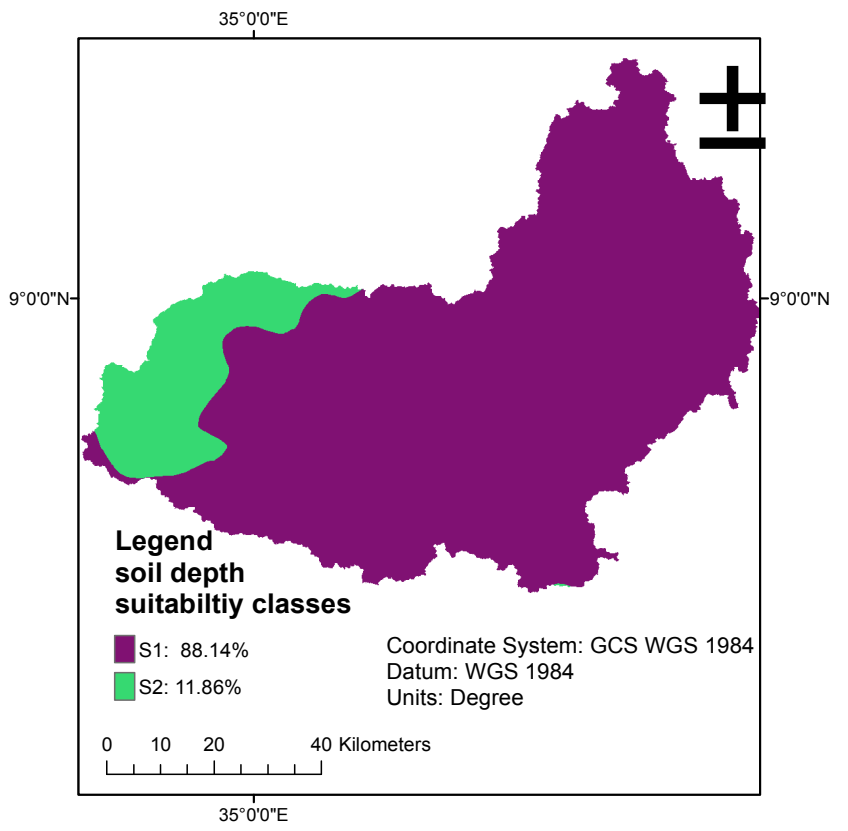

Figure 6. Reclassified soil depth class map of the watershed.

\subsubsection{Soil Depth Suitability}

Based on the guideline of land suitability evaluation [15], 
the study area has fall under only two ranges of soil depth. The soils depth identified in the study area were found to be deep to very deep which was ranging from $90 \mathrm{~cm}$ to even greater than $120 \mathrm{~cm}$. The depth class which is greater than $120 \mathrm{~cm}$ was classified as highly suitable (S1) whereas soil depth of $90 \mathrm{~cm}$ to 120 was classified as S2 (moderately suitable). The range of highly suitable was found to be $88.14 \%$ (559146 ha) of the total area whereas the rest part of the land $11.86 \%$ (75224) with soil depth of $90-120 \mathrm{~cm}$ was classified as S2 (moderately suitable class). The result in figure 6 shows highly suitable (S1) class on the map almost covered all area of watershed except small area of the lower part which is the part of moderately suitable class (S2).

\subsubsection{Soil Drainage Suitability}

Based on the FAO (1985) guideline of land suitability evaluation, the study area has fall under only three ranges of soil drainage. These are S1, S2 and N suitability classes and the final soil drainage suitability map of the watershed was developed accordingly as shown on Figure 7. ;A soil drainage class with well drainage was classified as highly suitable (S1), whereas moderate drainage and poor drainage were classified as S2 (moderately suitable) and N (marginally not suitable) respectively. The result in figure 7 shows highly suitable (S1) class on the soil drainage map is located at the middle and lower part of the watershed. The location of S1 for drainage is opposite of soil texture. This indicates that soil with good drainages has no good textures for surface irrigation.

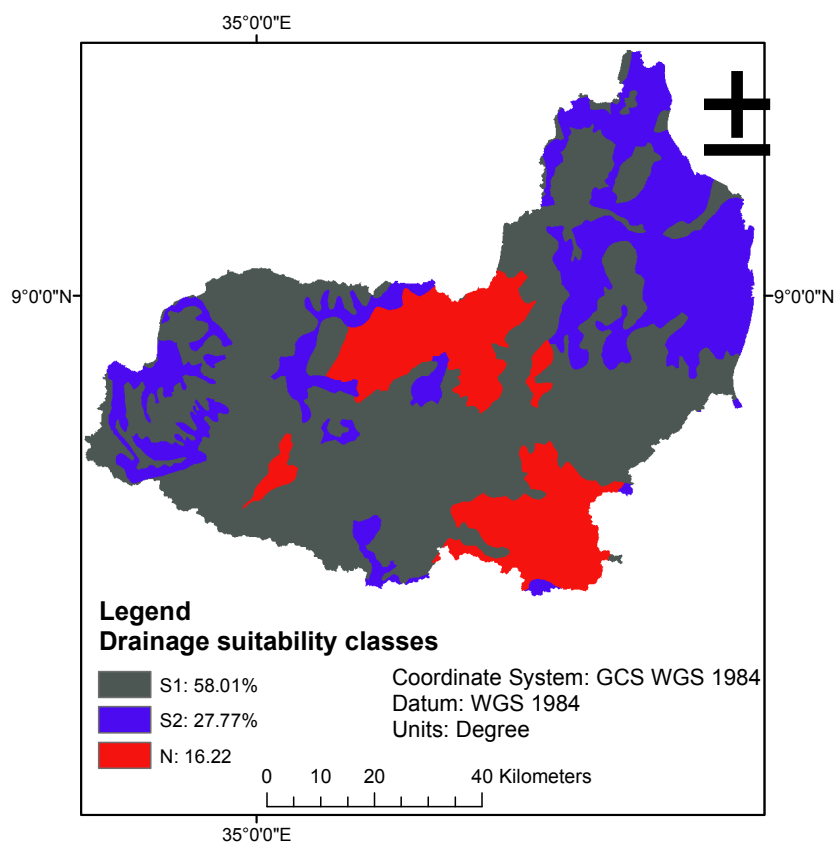

Figure 7. Reassailed soil drainage suitability map.

\subsubsection{Soil Type Suitability}

The soil type suitability analysis indicated that soil types classes such as Chromic cambisols, Humic nitosols, Haplic nitosols and Eutric fluvisols soil were classified as highly suitable (S1), similarly Haplic luvisols, Rhodic nitosols were classified as moderately suitable (S2) were as soil types such as Chromic luvisols, Haplic lixisols and Eutric gleysols were classified as marginally suitable (S3) for surface irrigation with limitation factor of their low fertility. As it can be observed from figure 8 , about $90 \%$ soils type of the Birbir river watershed were found to be suitable for surface irrigation if the limiting factor productivity and fertility of the land (S2 and S3) is improved and soil and water conservation practices was done.

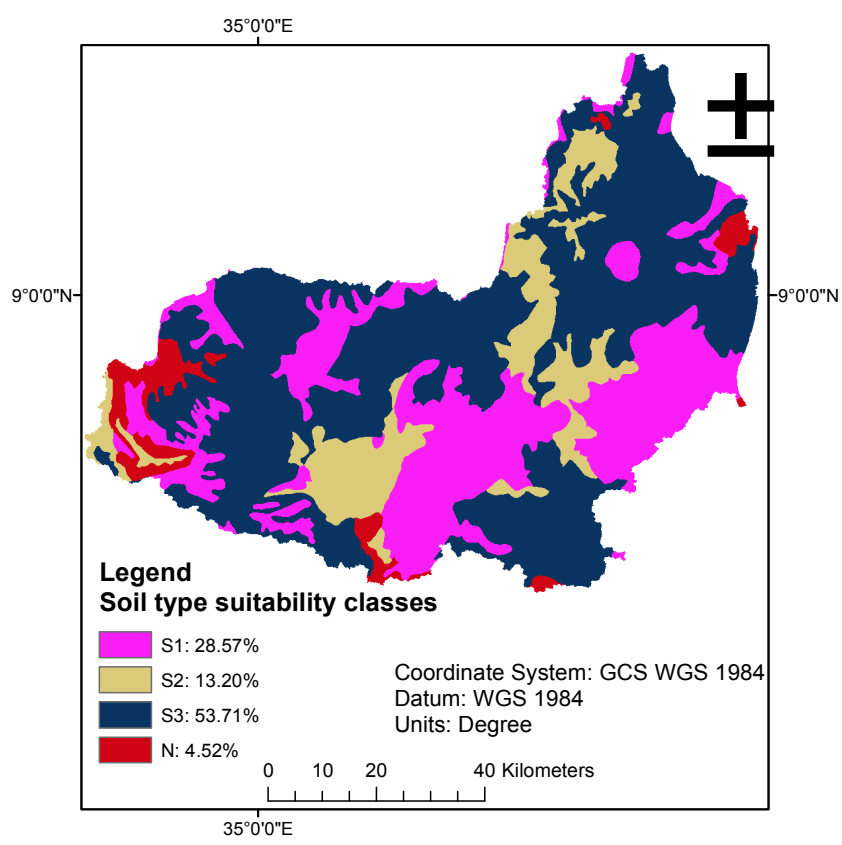

Figure 8. Reclassified soil type suitability map.

\subsubsection{Distance from Water Sources Suitability}

From the delineated Birbir River watershed, command areas which are closest to the water source were classified as high suitable (S1). This covers the range of distance from $0.03 \mathrm{~km}$ to $10 \mathrm{~km}$. Similarly as it can be observed, distance from $10 \mathrm{~km}$ to $20 \mathrm{~km}$ were classified as moderately suitable (S2) were as area between $20-30 \mathrm{~km}$ and greater than $30 \mathrm{~km}$ were classified as S3 (marginally suitable) and N (marginally not suitable) for surface irrigation with limitation of their greater distance. From figure 9 about more than $90 \%$ of the Birbir river watersheds were found to be suitable for surface irrigation even though the cost for application for this surface irrigation increases in the areas of S2 and S3 classes.

\subsection{Suitable Land for Surface Irrigation}

All parameters, which were selected for the evaluation of Land suitability for surface irrigation in the study area, were weighted and areal coverage and their percentage in the river watershed were shown in Table 3 and Figure 10. From Table 3 it can be observed that $17.03 \%$ (106223 ha) of the total area of the Birbir river watershed was found to be in the range of highly suitable (S1) for surface irrigation system with respect to all parameters of watershed land suitability. Around two third of the watershed or $62.92 \%$ (392232 ha) was found to be in the range of moderately suitable (S2) for surface irrigation 
land suitability, were as the remaining $20.05 \%$ (124947 ha) of the total area of the Birbir river watershed was found to be in the range of marginally suitable (S3) for surface irrigation method. The total area of the land classified as not suitable $\mathrm{N}$ class cover was not available. This implies that all areas of lands in the Birbir river watershed can be utilized based on the current irrigation technology.

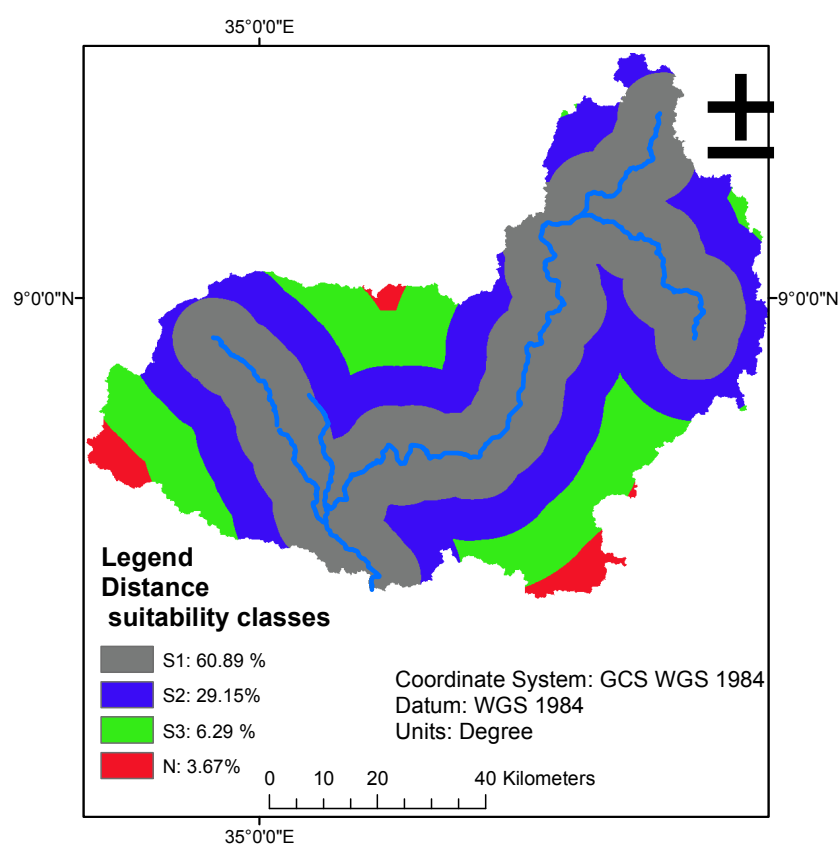

Figure 9. Reclassified distance map of command area.

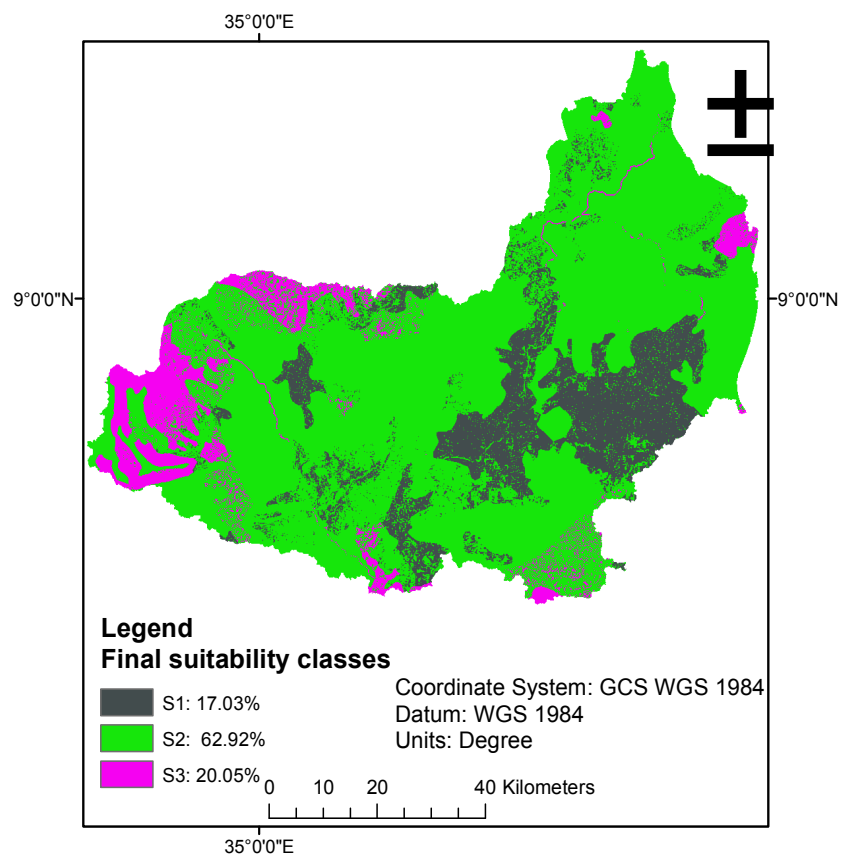

Figure 10. Final surface irrigation land suitability map.

The result in figure 10 shows that highly suitable (S1) class on the map is located at the upper and middle part of the river watershed. From this land suitability location it can be concluded that it might be difficult to irrigate all highly suitable (S1) land because enough amount of discharge cannot be accumulated at the middle part of the watershed. However, land suitability classes in the range of moderately suitable (S2) can get enough discharge than S1 since it is located at lower parts.

Table 3. Final Suitable surface irrigation land of the study area.

\begin{tabular}{llll}
\hline $\begin{array}{l}\text { Suitability } \\
\text { class }\end{array}$ & Area & & Suitability class name \\
\cline { 2 - 3 } & $\mathbf{( \% )}$ & (ha) & \\
\hline S1 & 17.03 & 106223 & Highly suitable \\
S2 & 62.92 & 392232 & Moderately suitable \\
S3 & 20.05 & 124947 & Marginally suitable \\
Total & 100 & 623402 & \\
\hline
\end{tabular}

\section{Conclusions and Recommendations}

\subsection{Summary and Conclusion}

Based on slope suitability analysis more than half Birbir river watershed was found to be highly suitable to moderately suitable for surface irrigation in terms of its work efficiency and cost for land leveling, canal construction and cost for pumping system. one fourth of the river watershed cannot be put under surface irrigation due to the impact of surface irrigation on the environment and almost half of the Birbir river watershed can be put under surface irrigation with some limitations which may cost the mitigation of the environment with respect to land use land cover. The texture suitability analysis showed that highly suitable ( $\mathrm{S} 1)$ class on the map almost covered all area of watershed except small area of the lower part which is the part of moderately suitable class (S2). The location of S1 for drainage is opposite of soil texture. This indicates that soil with good drainages has no good textures for surface irrigation. About 90\% Soil type of the Birbir river watershed were found to be suitable for surface irrigation if the limiting factor productivity and fertility of the land (S2 and S3) is improved and soil and water conservation practices was done. Even though the cost for application for this surface irrigation increases in the areas of S2 and S3 classes more than $90 \%$ of the Birbir river watersheds were found to be suitable for surface irrigation in terms of distance suitability. By weighting the values of these seven parameters data sets using weighted overlay in ArcGIS 10.3 , the irrigation suitability map was developed and land suitable for surface irrigation were found to be $17 \%, 63 \%$ and $20 \%$ for S1, S2, and S3 respectively. This result shows that highly suitable ( $\mathrm{S} 1)$ class on the map is located at the upper and middle part of the river watershed. From this land suitability location it can be concluded that it might be difficult to irrigate all highly suitable (S1) land area because enough amount of discharge cannot be accumulated at the middle part of the watershed. However, land suitability classes in the range of moderately suitable (S2) can get enough discharge than S1 since it is located at lower parts.

\subsection{Recommendations}

Result of the irrigation suitability analysis of the watershed indicated that, from the total area of the watershed, only $17 \%$ 
of the watershed is highly suitable for surface irrigation. Therefore, in order to increase the suitable irrigable land, suitability analysis for other methods of irrigation which are less affected by topography, such as sprinkler and drip irrigation should be carried out. In this study, the surface irrigation land suitability was carried out by considering only distance from the source, soil type; soil texture, soil drainage, slope, and land cover use as factor of suitability. However, there might be effects of other factors such as water quality, environmental impacts, economic importance of crops, ground water resource, and social terms should also be assessed to get sound and reliable result.

\section{Acknowledgements}

First and foremost, thanks to the Almighty God for granting me His limitless care, love and blessings all along the way. We are grateful to National Metrological Service Agency (NMSA), Ministry of Water, Electricity and Energy, Hydrology Department and Ethiopian Map Agency for providing the required data to conduct the study. Besides, our deep hearted gratitude goes to Jimma Institute of Technology, School of graduate studies for the invaluable knowledge and guidance for our study.

\section{References}

[1] FAO (Food and Agriculture Organization), 1997. Irrigation potential in Africa: A basin approach FAO Land and Water Bulletin 4.

[2] Saymen SW, 2005. Performance evaluation of furrow irrigation system and GIS-based gravity irrigation suitable area map development at Godino Mariam, Debrezeit. MSc thesis, Haremaya University.

[3] Yazew E. 2005. Development and management of irrigated lands in Tigray, Ethiopia. Thesis UNESCO-IHE Institute for Water Education. Delft, the Netherlands, 265.

[4] Belete Bantero, 2006. Across systems comparative assessment of Hare Community managed irrigation schemes performance. MSc thesis, Arba Minch University.

[5] Bihmani O., 2013. Opinions of the Management to Realize and Improve Water Productivity in Agriculture. Central
Statistical Agency, 2016. Central Statistical Agency of Ethiopia.

[6] FAO (Food and Agriculture Organization), 1994. Andreas P. S. and Karen F. Crop Water Requirements and Irrigation Scheduling. Water Resources Development and Management Officers FAO Sub-Regional Office for East and Southern Africa: Irrigation Manual Module 4. Harare, Zimbabwe.

[7] Federal Democratic Repulic of Ethiopia, 2011. Small-Scale Irrigation Capacity-building Strategy for Ethiopia. Addis Ababa, Ethiopia.

[8] MoWE (2013) Ministry of water and energy of Ethiopia: MoWR, Federal Democratic Republic of Ethiopia (FDRE), Addis Ababa.

[9] FAO (Food and Agriculture Organization), 1995. Guideline for Land Evaluation for Irrigated Agriculture. Soils Bulletin, 55. FAO, Rome.

[10] Jaruntorn B, Det W, Katsutoshi S., 2004. GIS based land suitability assessment for Musa. Graduate School of Agricultural science, Ethime University, Japan.

[11] FAO, 2007. Land evaluation towards a revised framework. Land and Water Discussion Paper 6, Rome.

[12] Fasina, A. S., G. O Awe, and J. O Aruleba, 2008. Irrigation suitability evaluation and crop yield an example with Amaranthus cruentus in Southwestern Nigeria. African Journal of Plant Science Vol. 2 (7), pp. 61-66, July 2008.

[13] Sander P., Chesley M. and Minor T. 1996. Groundwater assessment using remote sensing and GIS in a rural groundwater project in Ghana. Hydrogeology Journal, 4 (3), 78-93.

[14] FAO (Food and Agriculture Organization), 1999. Irrigation and water resources potential for Africa. FAO AGL/MISC/11/87. Rome, Italy.

[15] FAO (Food and Agriculture Organization), 1985. Guideline for Land Evaluation for Irrigated Agriculture. Soils Bulletin, 55. FAO, Rome.

[16] FAO (Food and Agriculture Organization), 1976. A framework for land evaluation. Soils Bulletin, No. 32 FAO, Rome Africa. FAO, Rome, Italy.

[17] Negash Wagesho, 2004. GIS Based Irrigation suitability analysis, A Case Study of AbayaChamo Basin Southern Rift Valley of Ethiopia. Jornal of Water Technology, Arba minch University Institute of Water Technology. 